AKRUAL 2 (2) (2011): 200-216 $e$-ISSN: 2502-6380

\title{
AKRUAL
}

Jurnal Akuntansi

http://fe.unesa.ac.id/ojs/index.php/akrl

\section{ANALISA DEVOLUSI BPHTB MENJADI PAJAK DAERAH DENGAN ECONOMIC OF COLLECTION SEBAGAI TOLAK UKUR (STUDY KASUS KABUPATEN MADIUN)}

\author{
Dewi Prastiwi \\ Fakultas Ekonomi Universitas Negeri Surabaya \\ Amanta Zain \\ Fakultas Ekonomi Universitas Negeri Surabaya \\ Yaman Suryaman \\ Fakultas Ekonomi Universitas Negeri Surabaya \\ Email: ardefira@yahoo.co.id
}

Diterima: 22 Januari 2011

Terakhir direvisi: 27 Maret 2011

\begin{abstract}
Act No. 28 of 2009 is a set of policies issued by the government to give more autonomy to local government to manage its finances. One form of financial autonomy is realized in the form of devolution of authority from central government tax collections to the regional government, one of which is BPHTB. However, based on survey results of the readiness of the region with local regulation readiness indicators, from the 492 area there are only about 160 areas that are ready to pick BPHTB. The remaining 108 are in the process of preparing regional and 224 local law there is no information. Of the 224 areas that there is still no information is largely disagreed with the existence of such PDRD Act.Hence, this study aims to analyze the devolution of Economic BPHTB with the principle of Collection as a benchmark (especially in Madiun County). The results showed that in Madiun County policy did not represent one of the principle of taxation at the Economics of Collection. The results of this study can be used by governments as an ingredient to evaluate BPHTB devolution in general and review the levels of NJOPTKP determination as provided in Act No. 28 of 2009.
\end{abstract}

Key words: Devolusi, BPHTB, Economic of Collection

\section{PENDAHULUAN \\ Otonomi Daerah}

Kebijakan otonomi daerah memberikan perubahan yang sangat mendasar dalam pengaturan hubungan Pusat dan Daerah, khususnya dalam bidang administrasi pemerintahan maupun dalam hubungan keuangan antara Pemerintah Pusat dan 
Daerah. Untuk lebih memberikan otonomi kepada Pemerintah Daerah dalam mengelola keuangannya, maka perlu dilakukan desentralisasi fiskal. Desentralisasi Fiskal merupakan pemberian kewenangan kepada daerah untuk menggali sumbersumber pendapatan, hak untuk menerima transfer dari pemerintah yang lebih tinggi, dan menentukan belanja rutin dan investasi.

Dalam rangka mewujudkan cita-cita dan tujuan bangsa seperti yang tertuang dalam Pembukaan Undang-undang Dasar 1945 yaitu mencapai masyarakat adil dan makmur baik material maupun spiritual (GBHN). Pembangunan yang sedang dilaksanakan sekarang ini mempunyai arti tersendiri karena memasuki era globalisasi dan perdagangan bebas Pemerintah Daerah dituntut untuk lebih menyiapkan diri sehingga mampu mengantisipasi sedini mungkin segala kemungkinan-kemumgkinan yang akan terjadi dalam persaingan yang datang dari luar negeri maupun persaingan yang datang dari dalam negeri sendiri.

Suatu negara dengan wilayah yang luas membutuhkan suatu sistem pemerintahan yang baik. Sistem ini sangat diperlukan setidaknya oleh dua hal: Pertama sebagai alat untuk melaksanakan berbagai pelayanan piblik di berbagai daerah. Kedua sebagai alat bagi masyarakat setempat untuk dapat berperan serta aktif dalam menentukan arah dan cara mengembangkan taraf hidupnya sendiri selaras dengan peluang dan tantangan yang dihadapi dalam koridor kepentingan-kepentingan nasional.

Untuk tujuan itu banyak yang harus kita lakukan, salah satunya adalah desentralisasi, yaitu pelimpahan tanggung jawab fiskal, politik dan administrasi kebijakan dari Pemerintah Pusat kepada Pemerintah Daerah di Indonesia lingkungan legal dan regulasi pokok untuk desentralisasi terangkum dalam tiga UU yaitu UU No.22 Tahun 1999 tentang Pemerintah Daerah, UU No.25 Tahun 1999 tentang Perimbangan Keuangan Antara Pemerintah Pusat dan Daerah, UU No.34 Tahun 2000 tentang Perubahan, UU RI No.18 Tahun 1997 tentang Pajak Daerah dan Retribusi Daerah. Ketiga UU tersebut tidak berdiri sendiri secara parsial, tetapi merupakan satu kesatuan untuk mewujudkan daerah otonom yang ekonomis, efisien, efektif, transparan, akuntabel dan responsif secara berkesinambungan.

Dalam UU No.22 Tahun 1999 dan UU No. 25 Tahun 1999, secara jelas disebutkan bahwa desentralisasi adalah kewenangan yang penuh dalam menyelenggarakan urusan rumah tangganya, mulai dari tahap perencanaan sampai dengan tahap pelaporan dan evaluasi. Kosekuensi logis dari desentralisasi tersebut, akan ada pelimpahan wewenang dan tanggung jawab dalam menggunakan dana, baik yang berasl dari Pemerintah Pusat (sesuai dengan urusan yang telah diserahkan) maupun dana yang berasal dari Pemerintah Daerah sendiri. Untuk pengelolaan dana yang cukup besar ini diperlukan juga peraturan pelaksana yang lebih kongkret dan lebih jelas, seperti Peraturan Pemerintah.

Pengalaman yang terjadi selamai ini menunjukkan bahwa manajemen keuangan daerah masih memprihatinkan. Anggaran daerah, khususnya pengeluaran daerah belum mampu berperan sebagai insentif dalam mendorong laju pembangunan di daerah. Di sisi lain banyak ditemukan pengalokasian anggaran yang tidak sesuai 
dengan kebutuhan dan skala prioritas dan kurang mencerminkan aspek ekonomi, efisiensi, dan efektivitas, karena kualitas perencanaan anggaran daerah relatif lemah. Lemahnya perencanaan anggaran juga diikuti dengan ketidakmampuan Pemerintah Daerah untuk meningkatkan penerimaan daerah secara berkesinambungan. Sementara itu pengeluaran daerah terus meningkat, sehingga hal tersebut meningkatkan fiscal gap. Keadaan ini pada akhirnya akan menimbulkan underfinancing atau overfinancing yang pada gilirannya akan mempengaruhi tingkat ekonomi, efesiensi dan efektivitas unit kerja Pemerintah Daerah.

Kondisi krisis ekonomi mengakibatkan semakin besarnya kesenjangan fiskal (fiscal gap) yang disebabkan pula oleh kapasitas fiskal daerah (local fiscal capasity) yang semakin rendah sejalan dengan turunnya aktivitas ekonomi sektor riil. Di satu sisi sumber pendapatan daerah yang berasal dari pemerintah pusat atau pemerintah atasannya semakin terbatas, di sisi lain kebutuhan fiskal (fiscal need) bertambah terus. Selain itu, belanja pemerintah daerah menjadi semakin besar karena kenaikan harga-harga barang. Kemudian beratnya beban pemerintah daerah dalam menjalankan peran ganda yang disebabkan melemahnya peran swasta dalam menjalankan aktivitasnya.

Pemerintah menyusun berbagai perangkat kebijakan dalam mengimplementasikan desentralisasi fiskal, diantaranya Undang-Undang Nomor 34 Tahun 2000 tentang Pajak Daerah dan Retribusi Daerah yang telah diperbarui menjadi Undang-undang Nomor 28 Tahun 2009 (UU PDRD). Undang-Undang tersebut memberikan otonomi lebih bagi Pemerintah Daerah untuk mengelola keuangannya. Salah satu wujud otonomi keuangan tersebut direalisasikan dalam bentuk pelimpahan kewenangan pemungutan pajak dari Pemerintah Pusat kepada Pemerintah Daerah.

Undang-Undang Nomor 28 Tahun 2009 diterbitkan dengan maksud untuk memperbaiki sistem pemungutan pajak dan retribusi di daerah, selain itu dimaksudkan juga sebagai pemberian kewenangan perpajakan yang lebih kepada daerah sehingga dapat meningkatkan efektivitas pengawasan perpajakan (Jawa Pos, Senin, 23 November 2009). Salah satu implikasi UU No. 28 tahun 2009 dari sisi penerimaan daerah adalah pengalihan PBB dan BPHTB menjadi pajak daerah dan perluasan basis pajak dan retribusi tertentu.

Kebijakan pemerintah tersebut diharapkan menguntungkan pemerintah daerah. Namun, berdasarkan hasil survey kesiapan daerah oleh Kemenkeu per tanggal 23 Desember 2010 dengan indicator kesiapan Perda, dari 492 daerah yang akan memungut BPHTB, hanya terdapat sekitar 160 daerah yang sudah siap memungut pajak itu. Sisanya sebanyak 108 daerah sedang dalam proses penyiapan Perda dan 224 daerah masih belum ada informasi. Dari 224 daerah yang masih belum ada informasi tersebut rupanya sebagian besar tidak setuju dengan adanya UU PDRD tersebut. Berikut adalah hasil survey kesiapan daerah dalam memungut BPHTB tahun 2011. 
Tabel 1. Hasil Survey per 23 Desember 2010

\begin{tabular}{clcc}
\hline No. & Kesiapan Daerah & Jumlah Daerah & $\begin{array}{c}\text { \% Penerimaan BPHTB } \\
\text { Tahun 2009 }\end{array}$ \\
\hline I. & Perda yang telah siap & 160 & 66,6 \\
II. & Raperda (dalam proses) & 108 & 18,7 \\
III. & Belum ada informasi & 224 & 14,7 \\
\hline
\end{tabular}

Sumber: Wahyudi (2010)

Implementasi UU PDRD membutuhkan beberapa hal sebagai berikut:

1. Peraturan Daerah sebagai dasar pemungutan BPHTB.

2. Sumber Daya Manusia yang memadai

3. Sarana dan prasarana (pelayanan) yang memadai untuk melancarkan proses penagihan

Semua hal yang harus disiapkan oleh Pemerintah Daerah tersebut memiliki berbagai persoalan dalam realitasnya. Persoalan yang timbul dari proses devolusi ini antara lain:

1. Kemampuan aparat daerah terutama dalam penetapan basis pajak dan pelayanan kepada masyarakat.

2. Perlu kemauan politik daerah untuk mengenakan tarif yang memadai dan/atau menerapkan sanksi yang keras berhubung terkait langsung dengan kepentingan politik penguasa yang bersangkutan di daerah.

3. Masih terbatasnya pengalaman daerah dalam pengembangan sistem informasi dan pengembangan infrastruktur penunjang.

4. Pemungutan BPHTB memerlukan orang-orang yang cakap dalam menginterpretasikan peraturan.

5. Diperlukan Peraturan Daerah untuk mengatur pelaksanaan pemungutan.

Untuk mengatasi semua persoalan tersebut tentu membutuhkan dana yang besar. Salah satu dari 160 kabupaten/kota yang siap melaksanakan pemungutan BPHTB, adalah pemerintah Kabupaten Madiun. Berdasarkan latar belakang tersebut diatas, penelitian ini ditujukan untuk menganalisis kebijakan devolusi BPHTB sebagai pajak daerah dengan economic of collection sebagai tolak ukur dengan study kasus pada Pemerintah kabupaten Madiun.

\section{KAJIAN PUSTAKA}

\section{Desentralisasi}

Desentralisasi adalah penyerahan wewenang pemerintah oleh Pemerintah Pusat kepada Daerah otonom dalam kerangka Negara Kesatuan Republik Indonesia. Ini berarti kekuasaan yang sebelumnya secara penuh berada di pemerintah pusat, kemudian diserahkan kepada pemerintah daerah khsusnya kabupaten/kota. Penyerahan kewenangan ini kemudian disertai penyerahan sumber-sumber pembiayaannya (money follows function). Terdapat banyak instrumen yang dapat 
dipergunakan oleh pemerintah daerah untuk membiayai seluruh pengeluaran yang dibebankan kepada pemda akibat desentralisasi dan otonomi daerah.

Secara garis besar, sumber pembiayaan (pendapatan) dapat diklasifikasikan dalam dua kategori sumber pembiayaan, yaitu external source dan local source. External source adalah pendapatan yang diperoleh pemerintah daerah dari sumbersumber di luar pemerintah daerah. Pendapatan ini merupakan pendapatan yang diperoleh dari sumber-sumber yang berasal dari pihak luar dan tidak secara langsung ditangani sendiri oleh pemerintah daerah. Yang dimaksud dengan pihak luar di sini adalah pihak-pihak yang berada di luar pemerintah daerah yang bersangkutan (selain pemerintah daerah beserta perangkatnya) dan bukan merupakan penduduk daerah yang bersangkutan, seperti pemerintah pusat, tingkatan pemerintahan yang ada di atas pemerintahan daerah yang bersangkutan, negara asing, pihak swasta, dan pihak ketiga.

Local source adalah pendapatan yang diperoleh pemerintah daerah dari sumber-sumber yang dikelola oleh pemerintah daerah itu sendiri. Kategori pendapatan yang kedua ini merupakan pendapatan yang digali dan ditangani sendiri oleh pemerintah daerah dari sumber-sumber pendapatan yang terdapat dalam wilayah yurisdiksinya. Pendapatan yang termasuk ke dalam kategori pendapatan ini adalah pajak daerah (local tax, subnational tax), retribusi daerah (local retribution, fees, local licence) dan hasil-hasil badan usaha (local ownedenterprises) yang dimiliki oleh daerah. Ketiga jenis pendapatan ini merupakan pendapatan yang digali dan ditangani sendiri oleh pemerintah daerah dari sumber-sumber pendapatan yang terdapat dalam wilayah yurisdiksinya.

Mardiasmo (2006:3) mengatakan bahwa dalam pemberdayaan pemerintah daerah ini, maka perspektif perubahan yang diinginkan dalam pengelolaan keuangan daerah dan anggaran daerah adalah:

1) Pengelolaan keuangan daerah harus bertumpu pada kepentingan publik (public oriented);

2) Kejelasan tentang misi pengelolaan keuangan daerah pada umumnya dan anggaran daerah pada khususnya;

3) Desentralisasi pengelolaan keuangan dan kejelasan peran para partisipan yang terkait dalm pengelolaan anggaran;

4) Kerangka hukum dan administrasi atas pembiayaan, investasi dan pengelolaan keuangan daerah;

5) Kejelasan tentang kedudukan keuangan DPRD, KDH dan PNS Daerah, baik rasio maupun dasar pertimbangannya;

6) Ketentuan tentang bentuk dan struktur anggaran, anggaran kinerja, dan anggaran multi-tahunan;

7) Prinsip pengadaan dan pengelolaan barang daerah yang lebih profesional;

8) Prinsip akuntansi pemerintah daerah, laporan kuangan, peran DPRD, peran akuntan publik dalam pengawasan, pemberian opini dan rating kinerja anggaran, dan transparansi informasi anggaran kepada publik; 
9) Aspek pembinaan dan pengawasan yang meliputi batasan pembinaan, peran asosiasi, dan peran anggota masyarakat guna pengembangan;

10) Pengembangan sistem informasi keuangan daerah untuk menyediakan informasi anggaran yang akurat dan pengembangan komimen pemerintah daerah terhadap penyebarluasan informasi.

\section{Devolusi}

Devolusi adalah pembentukan dan pemberdayaan unit-unit pemerintahan di tingkat lokal oleh pemerintah pusat dengan kontrol pusat seminimal mungkin dan terbatas pada bidang-bidang tertentu saja. Menurut Hanson (1964), bentuk desentralisasi devolusi juga dinamakan sebagai desentralisasi politik (political decentalization) ini karena wewenang yang diserahkan oleh pemerintah pusat kepada daerah adalah wewenang untuk mengambil keputusan-keputusan politik. Devolusi sering juga disebut sebagai democratic decentralization karena terjadinya penyerahan kewenangan atau kekuasaan kepada lembaga-lembaga perwakilan rakyat daerah yang dipilih atas dasar pemilihan.

\section{Jenis-Jenis Pajak}

Pajak yang berlaku di Indonesia secara umum dapat dibedakan menjadi Pajak Pusat dan Pajak Daerah. Pajak Pusat adalah pajak-pajak yang dikelola oleh Pemerintah Pusat yang dalam hal ini sebagian dikelola oleh Direktorat Jenderal Pajak - Departemen Keuangan. Sedangkan Pajak Daerah adalah pajak-pajak yang dikelola oleh Pemerintah Daerah baik di tingkat Propinsi maupun Kabupaten/Kota.

Bea Perolehan Hak atas Tanah dan Bangunan (BPHTB) di dalam UU Nomor 34 Tahun 2000) termasuk Pajak Pusat. Namun setelah diberlakukannya UU Nomor 28 Tahun 2009 (UU PDRD yang baru), Bea Perolehan Hak atas Tanah dan Bangunan (BPHTB) termasuk ke dalam pajak daerah. Berikut adalah perbandingan pajak daerah yang diatur pemerintah menurut Undang-Undang sebelum dan sesudah di perbarui. 
Tabel 2. Perbandingan pajak daerah yang diatur pemerintah menurut UndangUndang sebelum di perbarui

\begin{tabular}{lll}
\hline No. & $\begin{array}{l}\text { Undang-Undang No. 34 tahun 2000 } \\
\text { (Sebelum Diperbarui) }\end{array}$ & $\begin{array}{l}\text { Undang-Undang No. 28 tahun 2009 } \\
\text { (Setelah Diperbarui) }\end{array}$ \\
\hline 1 & Pajak Hotel & Pajak Hotel \\
2 & Pajak Restoran & Pajak Restoran \\
3 & Pajak Hiburan & Pajak Hiburan \\
4 & Pajak Reklame & Pajak Reklame \\
5 & Pajak Penerangan Jalan (PPJ) & Pajak Penerangan Jalan \\
6 & Pajak Parkir & Pajak Parkir \\
7 & Pajak Pengambilan Bahan Galian Gol. C & Pajak Mineral Bukan Logam dan \\
& & Batuan \\
8 & & Pajak Air Tanah \\
9 & & Pajak Sarang Burung Walet \\
10 & & PBB Pedesaan \& Perkotaan \\
11 & & Bea Perolehan Hak atas Tanah dan \\
& & Bangunan \\
\hline
\end{tabular}

Sumber: Wahyudi (2010)

Pajak Bea Perolehan Hak Atas Tanah dan Bangunan (BPHTB)

Bea Perolehan Hak atas Tanah dan Bangunan (BPHTB) adalah pajak yang dikenakan atas perolehan hak atas tanah dan bangunan. Perolehan hak atas tanah dan atau bangunan adalah perbuatan atau peristiwa hukum yang mengakibatkan diperolehnya hak atas tanah dan atau bangunan oleh orang orang pribadi atau badan (Mardiasmo 2009).

\section{Obyek BPHTB}

Objek BPHTB adalah perolehan hak atas tanah dan atau bangunan. Dalam buku Perpajakan edisi revisi 2009 yang ditulis oleh Mardiasmo, Perolehan hak atas tanah dan atau bangunan meliputi:

1. Pemindahan hak karena :

a. Jual beli

b. Tukar-menukar

c. Hibah

d. Hibah wasiat

e. Waris

f. Pemasukan dalam perseroan atau badan hukum lainnya.

g. Pemisahan hak yang mengakibatkan Peralihan

h. Penunjukkan pembeli dalam lelang

i. Pelaksanaan putusan hukum yang mempunyai kekuatan hukum tetap

j. Penggabungan usaha

k. Peleburan usaha

1. Pemekaran usaha 
m. Hadiah

2. Pemberian hak baru karena :

a. Kelanjutan pelepasan hak

b. Di luar pelepasan hak

Pengertian Hak atas Tanah adalah Hak atas Tanah sebagaimana dimaksud dalam Undang-Undang No. 5 Tahun 1960 tentang Peraturan Dasar Pokok-Pokok Agraria, Undang-Undang Nomor 16 Tahun 1985 tentang Rumah Susun, dan Peraturan Perundang-undangan yang Berlaku lainnya. Yang termasuk dalam kategori Hak atas Tanah adalah Hak Milik, Hak Guna Usaha, Hak Guna Bangunan, Hak Pakai, Hak Milik atas Satuan Rumah Susun dan Hak Pengelolaan.

\section{Tidak Termasuk Objek BPHTB}

Objek pajak yang tidak dikenakan BPHTB adalah objek pajak yang diperoleh:

1. Perwakilan Diplomatik, konsulat berdasarkan asas perlakuan timbal balik.

2. Negara untuk penyelenggaraan pemerintahan dan atau pelaksanaan pembangunan guna kepentingan umum

3. Badan atau perwakilan organisasi internasional yang ditetapkan dengan Keputusan Menteri dengan syarat tidak menjalankan usaha atau melakukan kegiatan lain di luar fungsi dan tugas badan usaha atau perwakilan organisasi tersebut

4. Orang pribadi atau badan karena konversi hak atau karena perbuatan hukum lain dengan tidak adanya perubahan nama

5. Orang pribadi atau badan karena wakaf

6. Orang pribadi atau badan yang digunakan untuk kepentingan ibadah

\section{Subjek BPHTB}

Subjek pajak adalah orang pribadi atau badan yang memperoleh hak atas tanah dan atau bangunan. Subjek pajak yang dikenakan kewajiban membayar pajak menjadi Wajib Pajak BPHTB menurut Undang-Undang BPHTB.

\section{Dasar Pengenaan BPHTB}

Dasar pengenaan BPHTB sebagaimana diatur dalam Pasal 87 Undang-undang Nomor 28 Tahun 2009 adalah sebagai berikut:

(1) Nilai Perolehan Objek Pajak sebagaimana dimaksud pada ayat (1), dalam hal:

a. jual beli adalah harga transaksi;

b. tukar menukar adalah nilai pasar;

c. hibah adalah nilai pasar;

d. hibah wasiat adalah nilai pasar;

e. waris adalah nilai pasar;

f. pemasukan dalam peseroan atau badan hokum lainnya adalah nilai pasar;

g. pemisahan hak yang mengakibatkan peralihan adalah nilai pasar; 
h. peralihan hak karena pelaksanaan putusan hakim yang mempunyai kekuatan hukum tetap adalah nilai pasar;

i. pemberian hak baru atas tanah sebagai kelanjutan dari pelepasan hak adalah nilai pasar;

j. pemberian hak baru atas tanah di luar pelepasan hak adalah nilai pasar;

k. penggabungan usaha adalah nilai pasar;

1. peleburan usaha adalah nilai pasar;

m. pemekaran usaha adalah nilai pasar;

n. hadiah adalah nilai pasar; dan/atau

o. penunjukan pembeli dalam lelang adalah harga transaksi yang tercantum dalam risalah lelang.

(2) Jika Nilai Perolehan Objek Pajak sebagaimana dimaksud pada ayat (2) huruf a sampai dengan huruf $\mathrm{n}$ tidak diketahui atau lebih rendah daripada NJOP yang digunakan dalam pengenaan Pajak Bumi dan Bangunan pada tahun terjadinya perolehan, dasar pengenaan yang dipakai adalah NJOP Pajak Bumi dan Bangunan.

(3) Besarnya Nilai Perolehan Objek Pajak Tidak Kena Pajak ditetapkan paling rendah sebesar Rp60.000.000,00 (enam puluh juta rupiah) untuk setiap Wajib Pajak.

(4) Dalam hal perolehan hak karena waris atau hibah wasiat yang diterima orang pribadi yang masih dalam hubungan keluarga sedarah dalam garis keturunan lurus satu derajat ke atas atau satu derajat ke bawah dengan pemberi hibah wasiat, termasuk suami/istri, Nilai Perolehan Objek Pajak Tidak Kena Pajak ditetapkan paling rendah sebesar Rp300.000.000,00 (tiga ratus juta rupiah).

(5) Nilai Perolehan Objek Pajak Tidak Kena Pajak sebagaimana dimaksud pada ayat (4) dan ayat (5) ditetapkan dengan Peraturan Daerah.

\section{Asas Pemungutan Pajak}

Asas pemungutan pajak menurut Adam Smith, seperti dikemukakan dalam buku An Inquiry into The Nature and Causes of The Wealth of Nation adalah sebagai berikut (IAI 2011):

1. Asas Equality

Pemungutan Pajak harus bersifat final, adil, dan merata. Pajak dikenakan kepada orang pribadi yang harus sebanding dengan kemampuan membayar pajak atau ability to pay dan sesuai dengan manfaat yang diterima. Adil dimaksudkan bahwa setiap wajib pajak menyumbangkan uang untuk pengeluaran pemerintah sebanding dengan kepentingan dan manfaatnya.

2. Asas Certainty

Penetapan pajak itu tidak ditentukan sewenang-wenang. Oleh karena itu, wajib pajak harus mengetahui secara jelas dan pasti pajak yang terutang, kapan harus dibayar, serta batas waktu pembayaran.

3. Asas Convenience of payment (Pay as You Earn) 
Kapan wajib pajak itu harus membayar pajak sebaiknya disesuaikan dengan saatsaat tidak menyulitkan wajib pajak, misalnya pada saat wajib pajak memperoleh penghasilan. Disebut juga sistem pay as you earn.

4. Asas Economy/ Asas Effeciency (Economic of collection)

Biaya pemungutan pajak diusahakan sehemat mungkin, jangan sampai terjadi biaya pemungutan pajak lebih besar dari hasil pemungutan pajak.

\section{Metode Penelitian}

Jenis penelitian ini menggunakan penelitian kualitatif deskriptif. Dengan fokus penelitian tentang analisis devolusi BPHTB menjadi Pajak Daerah dengan Economic of Collection sebagai tolak ukur.

\section{Sumber dan Jenis Data}

Data adalah suatu kenyataan yang diteliti. Dalam penelitian ini menggunakan kualitatif deskriptif. Sumber data diperoleh dari:

a. Sumber Data Primer

Sumber data primer adalah sumber data penelitian yang diperoleh secara langsung dari sumber asli dan tidak melalui media perantara. Sumber data primer diperoleh dari proses wawancara terhadap Kepala Bidang penetapana, pembukuan, dan penagihan serta beberapa staf yang terlibat dalam proses pemungutan BPHTB di Dinas Pendapatan dan Pengelolaan Keuangan Daerah Kabupaten Madiun.

b. Sumber Data Sekunder

Sumber data sekunder merupakan sumber data penelitian yang diperoleh peneliti secara tidak langsung melalui media perantara. Sumber data sekunder diperoleh dari dokumentasi, arsip-arsip, laporan, literatur dan buku.

\section{Teknik Pengumpulan Data}

Teknik pengumpulan data yang digunakan dalam penelitian ini adalah wawancara mendalam, daftar pertanyaan dan observasi.

a. Wawancara

Wawancara adalah teknik pengumpulan data dengan mengajukan pertanyaan langsung oleh pewawancara kepada responden, dan jawaban-jawaban responden dicatat atau direkam (Hasan, 2002:85).

b. Observasi

Observasi adalah suatu bentuk metode penelitian melalui pangamatan langsung terhadap hal-hal yang terjadi di lokasi penelitian yang berkaitan dengan penelitian, yang dilakukan dengan langsung maupun tidak langsung serta dapat dilakukan dengan proses perbandingan antara satu fenomena dengan fenomena yang lain (Hasan, 2002:86). Observasi dalam penelitian ini dilakukan di Dinas Pendapatan dan Pengelolaan Keuangan Daerah Kabupaten Madiun, khususnya di Bidang Penetapan, Pembukuan, dan Penagihan. 


\section{c. Dokumentasi}

Dokumentasi adalah teknik pengumpulan data yang tidak langsung ditujukan pada subjek penelitian, namun melalui dokumen (Hasan, 2002:87). Metode ini dilakukan untuk mengumpulkan data dari dokumen-dokumen untuk menujang penelitian. Dokumen yang digunakan dalam penelitian ini adalah laporan, dan dokumen lainnya.

\section{Instrumen Data}

Instrumen pengumpulan data adalah alat atau fasilitas yang digunakan oleh peneliti dalam mengumpulkan data agar pekerjaannya lebih mudah dan hasilnya lebih baik, lebih cermat, lengkap dan sistematis sehingga lebih mudah diolah (Suharsimi dalam Hasan, 2002:76).

\section{Analisis Data}

Analisis data dalam penelitian kualitatif dilakukan pada saat pengumpulan data berlangsung dan setelah selesai pengumpulan data dalam periode tertentu. Teknik analisis data yang digunakan dalam penelitian ini adalah analisis data kualitatif, mengikuti konsep yang diberikan Miles dan Huberman (dalam Rachman, 1992:120). Mereka mengemukakan bahwa aktifitas dalam analisis data kualitatif dilakukan secara interaktif dan berlangsung secara terus menerus pada setiap tahapan penelitian sehingga sampai tuntas, dan datanya sampai jenuh. Langkah-langkah analisis ditunjukkan pada gambar 1 .

Berdasarkan gambar 1, Milles dan Huberman (dalam Rachman, 1992:120) menjelaskan bahwa terdapat empat tahap analisis data yaitu:

\section{Pengumpulan data}

Peneliti mencatat semua data secara obyektif sesuai dengan hasil observasi dan wawancara di lapangan. Pengumpulan data ini diperoleh setelah melakukan pengamatan di Dinas Pendapatan dan Pengelolaan Keuangan Daerah Kabupaten Madiun.

\section{Reduksi data}

Yaitu memilih hal-hal pokok yang sesuai dengan fokus penelitian. Dimana reduksi data merupakan suatu bentuk analisis yang menajamkan, menggolongkan, mengarahkan, membuang yang tidak perlu dan mengorganisasi. Data yang telah direduksi memberikan gambaran yang lebih tajam tentang hasil pengamatan dan mempermudah peneliti untuk mencarinya sewaktu-waktu diperlukan. Dari hasil wawancara yang dilakukan, penulis memilah-milah data yang telah didapat dengan topik yang akan dibahas.

3. Penyajian data

Penyajian data berupa sekumpulan informasi yang telah tersusun yang memberi kemungkinan adanya penarikan kesimpulan dan pengambilan tindakan. Penyajian data merupakan analisis dalan bentuk uraian singkat, bagan, matriks, networks, chart, atau grafis, sehingga peneliti dapat menguasai data. Dengan penyajian data 
akan memudahkan untuk memahami apa yang terjadi, merencanakan kerja selanjutnya berdasarkan apa yang telah dipahami sebelumnya.

4. Penarikan kesimpulan atau Verifikasi

Sejak semula peneliti berusaha mencari makna dari data yang diperoleh. Verifikasi dapat dilakukan dengan singkat yaitu dengan cara mengumpulkan data baru. Dalam pengambilan keputusan, didasarkan pada reduksi data dan penyajian data yang merupakan jawaban atas masalah yang diangkat dalam penelitian.

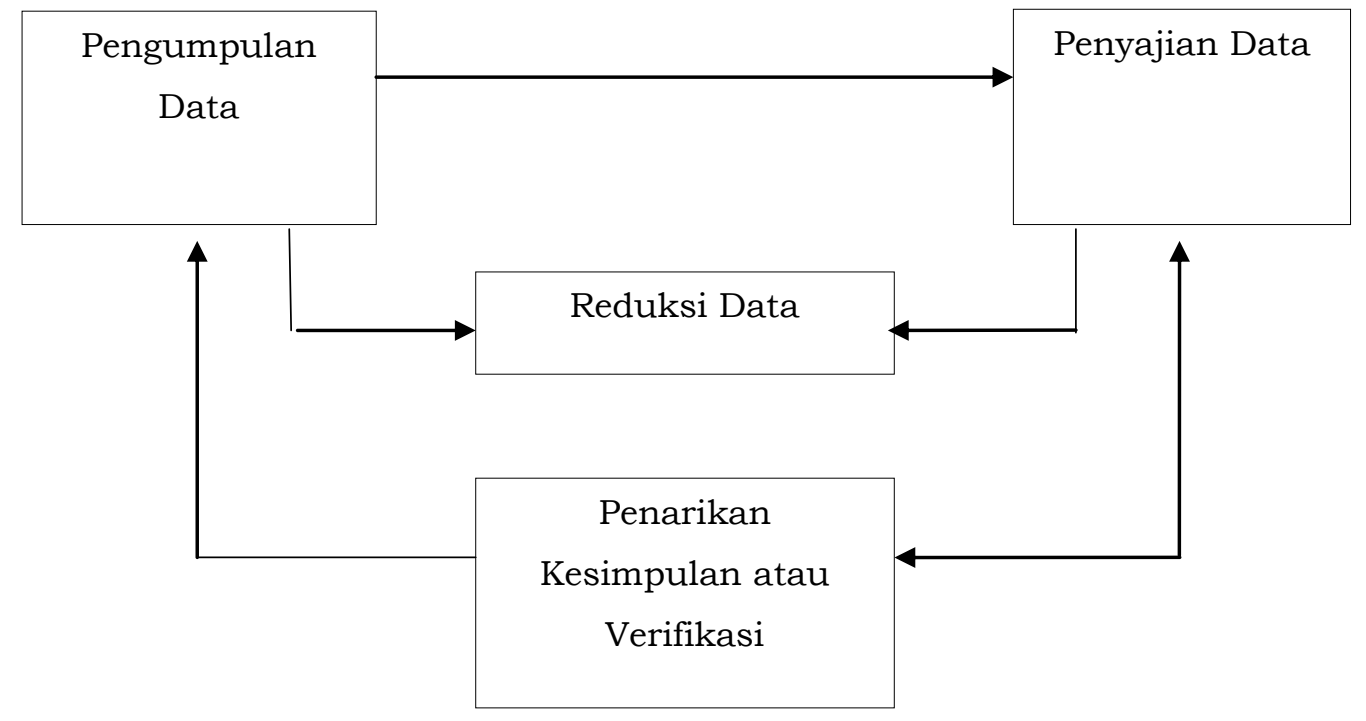

Sumber: Milles dan Huberman dalam Rachman (1992:120)

Gambar 1. Bagan Komponen dalam Analisis Data 


\section{Analisis dan Pembahasan}

Konsep otonomi daerah memberikan kewenangan yang lebih besar kepada daerah untuk mengelola dan mengatur pemerintahan serta sumber daya yang ada pada masing-masing daerah dalam kerangka Negara Kesatuan Republik Indonesia. Ini berarti kekuasaan yang sebelumnya secara penuh berada di pemerintah pusat, kemudian diserahkan kepada pemerintah daerah khsusunya kabupaten/kota. Penyerahan kewenangan ini kemudian disertai penyerahan sumber-sumber pembiayaannya (money follows function). Salah satu variabel untuk melihat kemampuan dan kemandirian pemerintah daerah dalam menjalankan otonominya, diukur melalui kinerja/kemampuan keuangan daerah. Beberapa variabel yang menunjukkan hal tersebut antara lain: kebutuhan fiskal (fiscal need), kapasitas fiskal (fiscal capacity), upaya fiskal (fiscal effort), derajat desentralisasi fiskal, serta koefisen elastisitas Pendapatan Asli Daerah (PAD) terhadap Product Domestic Regional Bruto (PDRB), (Musgrave \& Musgrave, 1980).

Desentralisasi Fiskal merupakan pemberian kewenangan kepada daerah untuk menggali sumber-sumber pendapatan, hak untuk menerima transfer dari pemerintah yang lebih tinggi, dan menentukan belanja rutin dan investasi. Dengan adanya desentralisasi fiskal, apabila Pemerintah Daerah melaksanakan fungsinya secara efektif, dan diberikan kebebasan dalam pengambilan keputusan penyediaan pelayanan di sektor publik, maka mereka harus didukung sumber-sumber keuangan yang memadai baik yang berasal dari Pendapatan Asli Daerah (PAD) termasuk surcharge of taxes, bagi hasil pajak dan bukan pajak, pinjaman, maupun subsidi/bantuan dari Pemerintah Pusat. Undang-undang Nomor 28 Tahun 2009 merupakan salah satu perangkat kebijakan yang dikeluarkan oleh Pemerintah untuk meningkatkan kemadirian fiscal pemerintah daerah dengan mendaerahkan BPHTB dan PBB.

Undang-undang Nomor 28 Tahun 2009 mengatur devolusi BPHTB yang efektif harus dijalankan oleh Pemerintah Kab/Kota per 1 Januari 2011. Namun dalam pelaksanaannya, 224 Pemerintah Kab/Kota menolak devolusi BPHTB dengan alasan cost of collection BPHTB tinggi dan tidak sebanding dengan penerimaannya.

Kabupaten Madiun merupakan salah satu dari 160 Pemerintah Kabupaten/Kota yang secara efektif menjalankan pemungutan BPHTB per 1 Januari 2011. Untuk menjalankan devolusi BPHTB tersebut, Kabupaten Madiun telah menyiapkan beberapa hal, diantaranya:

a. Peraturan Daerah No. 12 Tahun 2010 tentang Pajak Daerah

b. Peraturan Bupati No. 11 Tahun 2011 tentang Prosedur Pemungutan BPHTB

c. Update data harga tanah dan bangunan di 5 wilayah kecamatan (dalam proses).

Beberapa hal lain yang akan dipersiapkan di tahun anggaran berikutnya untuk memperlancar proses pemungutan BPHTB adalah:

a. Data Wajib Pajak/Obyek Pajak

b. Software yang mengintegrasikan pembayaran BPHTB dengan data Wajib Pajak /Obyek Pajak PBB

c. Sarana dan prasarana kantor pelayanan. 
Sedangkan dari sisi penerimaan, berdasarkan data Dinas Pendapatan dan Pengelolaan Keuangan Daerah Kabupaten Madiun sampai dengan November 2011 penerimaan BPHTB dapat dilihat pada tabel 2.

Berdasarkan hasil wawancara dengan Kepala Bidang Penetapan, Pembukuan, dan Penagihan Dinas Pendapatan dan Pengelolaan Keuangan Daerah Kabupaten Madiun, untuk mempersiapkan Perda, Perbub, dan Update harga tanah dan bangunan di 5 wilayah kecamatan memerlukan anggaran yang besarnya lebih dari penerimaan BPHTB tahun ini (tidak bersedia menyebutkan angka).

Sedangkan untuk mempersiapkan data Wajib Pajak/Obyek Pajak, Software yang mengintegrasikan pembayaran BPHTB dengan data Wajib Pajak /Obyek Pajak PBB serta penyediaan sarana dan prasarana kantor pelayanan dibutuhkan anggaran tiga sampai dengan empat kali lipat dari penerimaan BPHTB tahun ini.

Kondisi ini bagi Pemerintah Kabupaten Madiun sangat memberatkan anggaran, karena masih banyak sektor lain yang membutuhkan pembiayaan. Sedangkan sebelum dikeluarkan Undang-undang Nomor 28 Tahun 2009, dimana BPHTB masih menjadi pajak pusat, daerah menerima dana penerimaan bagi hasil BPHTB. Penerimaan dana bagi hasil BPHTB Pemerintah Kabupaten Madiun Tahun 2009 dan 2010 dapat dilihat pada tabel 3.

Tabel 2. Data Penerimaan BPHTB Per Kecamatan Pemerintah Daerah Kabupaten Madiun

\begin{tabular}{lccc}
\hline No & Kecamatan & Perolehan BPHTB & Ket/Dasar Penetapan \\
\hline 1 & Mejayan & 230.020 .950 & NJOP \\
\hline 2 & Wonoasri & 68.829 .200 & NJOP \\
\hline 3 & Dagangan & 15.829 .000 & NJOP \\
\hline 4 & Jiwan & 68.693 .500 & NJOP \\
\hline 5 & Madiun & 48.968 .500 & NJOP \\
\hline 6 & Saradan & 44.403 .000 & NJOP \\
\hline 7 & Balerejo & 38.875 .000 & NJOP \\
\hline 8 & Kebonsari & 22.642 .800 & NJOP \\
\hline 10 & Sawahan & 2.640 .000 & NJOP \\
\hline 11 & Geger & 52.818 .225 & NJOP \\
\hline 12 & Pilangkenceng & 3.032 .000 & NJOP \\
\hline 13 & Dolopo & 86.445 .375 & Seluruh transaksi di bawah \\
\hline 14 & Gemarang & Nihil & NJOP \\
\hline 15 & Kare & 11.015 .375 & NJOP
\end{tabular}

Sumber : Dinas Pendapatan dan Pengelolaan Pemkab Madiun 
Tabel 3. Data Penerimaan Bagi Hasil BPHTB Tahun 2009 dan 2010

\begin{tabular}{ccccc}
\hline Tahun & Uraian & Target & Realisasi & \% \\
\hline 2010 & Bagi Hasil dari BPHTB & $3,444,988,976$ & $4,200,988,731$ & 121.94 \\
\hline & & $2,400,000,000$ & $3,492,733,057$ & 145.53 \\
\hline \multicolumn{2}{l}{ Sumber : Dinas Pendapatan dan Pengelolaan Pemkab Madiun } & &
\end{tabular}

Sumber : Dinas Pendapatan dan Pengelolaan Pemkab Madiun

Penerimaan BPHTB karena adanya devolusi sangat jauh dengan penerimaan dana bagi hasil. Jika dianalisa, cost of collection BPHTB dibandingkan dengan penerimaanya maka anggaran Pemerintah Daerah Kabupaten Madiun mengalami defisit. Kondisi ini tidak memenuhi azas pemungutan pajak sebagaimana yang diungkapkan oleh Adam Smith, dalam buku An Inquiry into The Nature and Causes of The Wealth of Nation dimana salah satu azas pemungutan pajak adalah azas Economic of collection yaitu biaya pemungutan pajak diusahakan sehemat mungkin, jangan sampai terjadi biaya pemungutan pajak lebih besar dari hasil pemungutan pajak.

Ada beberapa hal yang menyebabkan penerimaan BPHTB di wilayah Kabupaten Madiun kecil, diantaranya:

1. Dasar pengenaan BPHTB adalah nilai perolehan obyek pajak sebagaimana yang diatur dalam pasal 87 ayat (1). Nilai perolehan obyek pajak dalam transaksi jual beli adalah harga transaksi, dsb sebagaimana yang diatur dalam ayat (2). Namun dalam prakteknya dasar pengenaannya adalah NJOP PBB yang nilainya sangat jauh dari harga pasar. Namun hal ini diperbolehkan berdasarkan Undang-undang Nomor 28 Tahun 2009 pasal 87 ayat (3) yang berbunyi: Jika Nilai Perolehan Objek Pajak sebagaimana dimaksud pada ayat (2) huruf a sampai dengan huruf $n$ tidak diketahui atau lebih rendah daripada NJOP yang digunakan dalam pengenaan Pajak Bumi dan Bangunan pada tahun terjadinya perolehan, dasar pengenaan yang dipakai adalah NJOP Pajak Bumi dan Bangunan. Pasal ini banyak digunakan oleh Wajib Pajak dalam menghitung besarnya BPHTB karena pasal ini menguntungkan bagi Wajib Pajak dan mudah mendapatkannya (berdasarkan SPPT PBB).

2. Dalam Pasal 87 ayat (4) besarnya NJOPTKP ditetapkan paling rendah sebesar Rp60.000.000,00 (enam puluh juta rupiah) untuk setiap Wajib Pajak.

3. Transaksi jual beli tanah di wilayah Kabupaten Madiun kebayakan merupakan tanah basah yang nilainya dibawah Rp. 60.000.000, sehingga lolos dari pembayaran BPHTB.

Untuk mengatasi berbagai permasalahan tersebut, secara bertahap pemerintah kabupaten Madiun menyusun Perbub tentang harga tanah dan bangunan di wilayah kabupaten Madiun yang akan digunakan sebagai dasar penghitungan BPHTB. Untuk saat ini baru dilaksanakan di 5 wilayah kecamatan. Dengan update data harga tanah dan bangunan ini diharapkan ada gambaran harga pasar tanah dan bangunan yang 
dapat digunakan sebagai dasar pemungutan BPHTB sehingga kemadirian fiscal yang diharapkan dapat tercapai.

\section{SIMPULAN}

Berdasarkan hasil analisa data penerimaan BPHTB dan anggaran yang dibutuhkan untuk mempersiapkan mekanisme pemungutan BPHTB, devolusi BPHTB kurang tepat karena tidak memenuhi azas Economic of Collection. Tingginya Cost of Collection disebabkan oleh: (a) dasar perhitungan pengenaan BPHTB adalah NJOP PBB yang nilainya jauh dari harga pasar; (b) untuk wilayah Kabupaten Madiun NJOPTKP yang telah ditetapkan dalam Undang-undang PDRD terlalu tinggi sehingga banyak transaksi pengalihan hak yang lolos dari pembayaran BPHTB. 


\section{DAFTAR PUSTAKA}

Andi, FerryAfi. 2010. Analisa Dampak Pemindahan Kewenangan Pemungutan Bea Peralihan Hak Atas Tanah dan/atauBangunan Kepada Pemerintah Daerah Terhadap Kemandirian Keuangan Daerah. http://ferryafiandi.blogspot.com/2011/06/analisa-dampak pemindahankewenangan.html

Bambang. 2011. Pengalihan Pungutan BPHTB dari Pusat ke Daerah yang Masih Bermasalah, http://bambangoyong.blogspot.com/2011/03/pengalihan-pungutanbphtb-dari-pusat-ke.html

Darise, Nurlan. 2009. Pengelolaan Keuangan Daerah: Pedoman untuk Eksekutif dan Legislatif Rangkuman 7 Undang-Undang, 30 Peraturan Pemerintah dan 15 Permendagri, Indeks, Jakarta.

IAI. 2011. Modul Pelatihan Pajak Terapan Brevet A \& B Terpadu. Jakarta: IAI.

Lubis, Abu Samman. 2011. Dampak Pengalihan BPHTB Bagi Pemerintah Kabupaten/Kota,http://www.bppk.depkeu.go.id/bdk/pontianak/index.php?optio $\mathrm{n}=$ com_content\&view=article\&id=74:dampak-pengalihan-bphtb-bagipemerintah-kabupatenkota\&catid=10:umum

Musgrave \& Musgrave. 1980. Akuntansi Sektor Publik. Jakarta: Erlangga.

Mardiasmo. 2009. Perpajakan Edisi Revisi 2009. Yogyakarta: ANDI.

M. Nasir. 2008. DEVOLUSI :Konsep Desentralisasi Demokratis, By.M.Nasir, S.IP, MPA. http://nasirforkombia.wordpress.com/2008/12/16/devolusi-konsepdesentralisasi-demokratis-bymnasir-sip-mpa/

Saidi, M. Djafar. 2008, Hukum Keuangan Negara, PT Rajagrafindo Persada, Jakarta.

Suparmoko, Muhammad. 2008. Keuangan Negara dalam Teori dan Praktek, BPFE, Yogyakarta.

Syamsi S.U, Ibnu. 1994. Dasar-Dasar Kebijaksanaan Keuangan Negara, PT. RinekaCipta, Jakarta.

Undang-UndangNomor 21 Tahun 1997 s.t.t.d UndangUndang Nomor 20 Tahun 2000 tentang Bea PerolehanHakatas Tanah dan/atauBangunan

Undang-Undang Nomor 28 Tahun 2009 tentang Pajak Daerah dan Retribusi Daerah.

Wahyudi, Eddi. 2010. Mulai 1 Januari 2011 BPHTB Telah ResmiMenjadi Pajak Daerah, http://eddiwahyudi.wordpress.com/2010/12/31/mulai-1-januari2011-bphtb-telah-resmi-menjadi-pajak-daerah/

Widjaja, Gunawan. 2002. Seri Keuangan Publik: Pengelolaan Harta Kekayaan Negara, SuatuTinjauanYuridis, PT Rajagrafindo Persada, Jakarta. 